\title{
GAMBARAN TINGKAT PENGETAHUAN DAN PERILAKU KEPALA KELUARGA TENTANG PEMBERANTASAN SARANG NYAMUK DEMAM BERDARAH DENGUE DI WILAYAH KERJA PUSKESMAS KUTA SELATAN
}

\author{
I Made Dwi Sutakresna ${ }^{1}$, Ni Made Marwati ${ }^{2}$
}

\begin{abstract}
Indonesia which is a tropical country in general has a risk of contracting DHF. DHF attacks have broad implications for material and moral loss, work productivity and the most fatal is the loss of life. Badung regency is one of districts in Bali which is endemic area of DHF. According to data from Badung District Health Office in 2017, the number of DHF cases in 2017 was 941 cases with death rate 1 person (Incidence Rate: 146.2 per 100,000 population and CFR I death rate: $0.11 \%$ ). The purpose of this research is to know description of head of household's knowledge and behavior on the eradication mosquito nest of dengue hemorrhagic fever in the working region of the Community Health Centre South Kuta. Type of research used is descriptive research. The sample size of this study was 96 Family Heads. The dominant male respondent characteristic is 67 people (70\%), age is dominated by 46-60 years ie 52 people (54\%) and high school education (51\%). The result of this research is 96 people of head of household's all have good knowledge level category about the eradication mosquito nest of dengue hemorrhagic fever. While the behavior of head of household's about the eradication mosquito nest of dengue hemorrhagic fever got 14 people $(14,6 \%)$ have enough behavioral category, while the rest as many as 82 people of head of household's $(85,4 \%)$ have good behavioral category.
\end{abstract}

Keywords : The Eradication Mosquito Nest of Dengue Hemorrhagic Fever, Knowledge, Behavior, Head of Household's

\section{PENDAHULUAN}

Demam Berdarah Dengue (DBD) merupakan penyakit yang banyak ditemukan di sebagian besar wilayah tropis dan subtropics. Host alami DBD adalah manusia, agentnya adalah virus dengue yang termasuk ke dalam famili Flaviridae dan genus Flavivirus, terdiri dari 4 serotipe yaitu Den-1, Den-2, Den3 dan Den-4
1. Indonesia yang merupakan negara tropik secara umum mempunyai risiko terjangkit penyakit DBD. Vektor penyebabnya yaitu nyamuk Aedes aegypti tersebar luas di kawasan pemukiman maupun tempat-tempat umum, kecuali wilayah pada ketinggian lebih dari 1000 meter di atas permukaan laut. 
Serangan penyakit DBD berimplikasi luas terhadap kerugian material dan moral ${ }^{2}$.

Menurut Profil Dinas Kesehatan Provinsi Bali tahun 2017, di Bali pada tahun 2017 jumlah penderita DBD yang dilaporkan sebanyak 4.487 kasus dengan jumlah kematian 12 orang (Incidence Rate (IR)/Angka Kesakitan: 105,9 per 100.000 penduduk dan CFR/angka kematian: 0,267\%). Jumlah kasus tertinggi terjadi di Kabupaten Badung.. Menurut data Dinas Kesehatan Kabupaten Badung tahun 2017, jumlah penderita DBD pada tahun 2017 sebanyak 941 kasus dengan jumlah kematian 1 orang (IR /Angka Kesakitan: 146,2 per 100.000 penduduk dan CFR/angka kematian: 0,11\%). Jumlah kasus terbanyak ada di wilayah kerja Puskesmas Kuta Selatan sebanyak 201 kasus (laki-laki sebanyak 121 kasus, perempuan sebanyak 80 kasus). Adapun Angka Bebas Jentik Puskesmas Kuta Selatan tahun 2017 sebesar 94,5\%. Angka ini masih di bawah target nasional sebesar $95 \%$.

Pada hakekatnya penularan DBD tidak terlepas dari pengetahuan dan perilaku dari masyarakat yang bersangkutan. Hal ini diperkuat kembali dengan teori HL Blum yang menyatakan bahwa aspek perilaku merupakan salah satu faktor yang mempengaruhi status kesehatan. Dampak dari perilaku terhadap derajat kesehatan cukup besar (30$35 \%$ ) terhadap derajat kesehatan), maka diperlukan berbagai upaya untuk mengubah perilaku yang tidak sehat menjadi sehat ${ }^{3}$. Proses yang didasari oleh pengetahuan kesadaran dan sikap positif, maka perilaku tersebut akan bersifat langgeng. Sebaliknya apabila perilaku tersebut tidak didasari oleh pengetahuan dan kesadaran maka tidak akan berlangsung lama ${ }^{4}$. Salah satunya dalam upaya PSN DBD.

Dalam Peraturan Pemerintah Nomor 21 tahun 1994 menyebutkan fungsi keluarga termasuk kepala keluarga di dalamnya mempunyai fungsi dalam pembinaan lingkungan, yaitu mengelola kehidupan keluarga dengan tetap memelihara lingkungan sekitarnya ${ }^{5}$.

Berdasarkan uraian di atas perlu dilakukan penelitian untuk mengetahui gambaran tingkat pengetahuan dan perilaku kepala keluarga mengenai PSN DBD di 
wilayah kerja Puskesmas Kuta Selatan. Tujuan penelitian ini adalah mengetahui gambaran tingkat pengetahuan dan perilaku $\mathrm{KK}$ mengenai PSN DBD di wilayah kerja Puskesmas Kuta Selatan. Manfaat praktis dari penelitian ini adalah mengetahui gambaran tingkat pengetahuan dan perilaku kepala keluarga mengenai PSN DBD di wilayah kerja Puskesmas Kuta Selatan. Manfaat teoritis dari penelitian ini adalah penelitian ini diharapkan dapat menjadi referensi atau masukan bagi perkembangan ilmu pengetahuan khususnya mengenai upaya PSN DBD.

\section{METODE}

Penelitian ini dilakukan di wilayah kerja Puskesmas Kuta Selatan. Penelitian ini dilaksanakan mulai dari penyusunan usulan penelitian hingga selesainya penelitian ini dari bulan Februari sampai dengan Juli tahun 2018. Jenis Penelitian ini adalah penelitian deskriptif dengan menggunakan lembar kuesioner. Besar sampel dalam penelitian ini adalah $96 \mathrm{KK}$ dari jumlah populasi sebanyak 25.996 KK. Penentuan besar sampel sesuai jumlah penduduk masing-masing desa ditentukan dengan cara proporsional. Adapun besar sampel tiap desa/kelurahan antara lain Desa Kutuh 3 KK, Desa Ungasan 11 KK, Desa Pecatu 8 KK, Kelurahan Benoa 27 KK, Kelurahan Jimbaran 42 KK dan Kelurahan Tanjung Benoa 5 KK. Adapun proses pemilihan rumah yang akan dikunjungi dengan teknik unprobability sampling. Dalam unprobability sampling, teknik yang digunakan adalah sampling insidental.

\section{HASIL}

Subyek dalam penelitian ini adalah 96 orang KK di wilayah kerja UPT Puskesmas Kuta Selatan. Adapun karakteristik dari subyek penelitian ini yaitu:

\section{Tabel 1}

Distribusi Frekuensi Berdasarkan Jenis Kelamin Kepala Keluarga

\begin{tabular}{ccc}
\hline $\begin{array}{c}\text { Jenis } \\
\text { Kelamin }\end{array}$ & Frekuensi & $\begin{array}{c}\text { Persentase } \\
(\mathbf{\%})\end{array}$ \\
\hline Laki-laki & 67 & 69,79 \\
Perempuan & 29 & 30,21 \\
\hline Total & $\mathbf{9 6}$ & $\mathbf{1 0 0}$
\end{tabular}

Tabel di atas menunjukkan bahwa jenis kelamin dari 96 orang $\mathrm{KK}$ di wilayah kerja UPT Puskesmas Kuta Selatan didominasi oleh jenis 
kelamin laki-laki yaitu 67 orang $(69,79 \%)$.

Tabel 2

Distribusi Frekuensi Berdasarkan Umur Kepala Keluarga

\begin{tabular}{ccc}
\hline $\begin{array}{c}\text { Jenis } \\
\text { Kelamin }\end{array}$ & Frekuensi & $\begin{array}{c}\text { Persentase } \\
(\%)\end{array}$ \\
\hline $\mathbf{2 0 - 3 2}$ & 14 & 14,58 \\
$\mathbf{3 3 - 4 5}$ & 30 & 31,25 \\
$\mathbf{4 6 - 6 0}$ & 52 & 54,17 \\
\hline Total & $\mathbf{9 6}$ & $\mathbf{1 0 0}$
\end{tabular}

Tabel di atas menunjukkan bahwa umur 96 orang KK di wilayah kerja UPT Puskesmas Kuta Selatan didominasi umur 46-60 tahun yaitu 52 orang $(54,17 \%)$.

Tabel 3

Distribusi Frekuensi Berdasarkan Tingkat Pendidikan Kepala Keluarga

\begin{tabular}{ccc}
\hline $\begin{array}{c}\text { Tingkat } \\
\text { Pendidikan }\end{array}$ & Frekuensi & Persentase (\%) \\
\hline SLTA & 51 & 53,12 \\
Akademi & 33 & 34,37 \\
Perguruan & 12 & 12,51 \\
Tinggi & & \\
\hline Total & $\mathbf{9 6}$ & $\mathbf{1 0 0}$ \\
\hline
\end{tabular}

Tabel di atas menunjukkan bahwa pendidikan 96 orang KK di wilayah kerja UPT Puskesmas Kuta Selatan didominasi oleh SMA yaitu 51 orang $(53,12 \%)$.
Tabel 4

Nilai Item Kuesioner Pengetahuan

\begin{tabular}{|c|c|c|c|c|}
\hline No & Pertanyaan & Salah & Benar & Jumlah Nilai \\
\hline 1 & P1 & 0 & 96 & 96 \\
\hline 2 & $\mathrm{P} 2$ & 0 & 96 & 96 \\
\hline 3 & P3 & 0 & 96 & 96 \\
\hline 4 & P4 & 18 & 78 & 18 \\
\hline 5 & P5 & 1 & 95 & 95 \\
\hline 6 & P6 & 0 & 96 & 96 \\
\hline 7 & P7 & 13 & 83 & 13 \\
\hline 8 & P8 & 17 & 79 & 17 \\
\hline 9 & P9 & 0 & 96 & 96 \\
\hline 10 & P10 & 1 & 95 & 95 \\
\hline 11 & P11 & 51 & 45 & 51 \\
\hline 12 & $\mathrm{P} 12$ & 0 & 96 & 96 \\
\hline 13 & P13 & 0 & 96 & 96 \\
\hline 14 & P14 & 70 & 26 & 26 \\
\hline 15 & P15 & 0 & 96 & 96 \\
\hline 16 & P16 & 3 & 93 & 93 \\
\hline 17 & P17 & 0 & 96 & 96 \\
\hline 18 & P18 & 0 & 96 & 96 \\
\hline 19 & P19 & 45 & 51 & 45 \\
\hline 20 & $\mathrm{P} 20$ & 60 & 36 & 36 \\
\hline 21 & $\mathrm{P} 21$ & 95 & 1 & 95 \\
\hline \multicolumn{4}{|c|}{ RATA-RATA } & 73,52 \\
\hline
\end{tabular}

Berdasarkan tabel di atas dapat dilihat bahwa dari 21 pertanyaan rata-rata nilai tiap pertanyaan yang di jawab oleh 96 KK adalah 73,52. Dari 21 pertanyaan, nilai pertanyaan yang masih di bawah rata-rata antara lain pertanyaan nomor 4 (Nyamuk penular penyakit DBD berkembangbiak di air kotor), 7 (Fogging atau diasapi lebih efektif menanggulangi penyakit DBD dibandingkan dengan cara PSN), 8 (Aturan waktu minimal dalam pemantauan jentik nyamuk dan PSN 
3M plus adalah satu bulan sekali), 11

(Menaburkan bubuk abate di tempat penampungan air boleh sekiranya tanpa aturan), 14 (Menutup lubang pohon termasuk kegiatan PSN), 19 (Kegiatan 3 M plus dirumah hanya boleh dilakukan orang tertentu saja), dan 20 (Memelihara ikan di bak mandi termasuk kegiatan PSN).

Tabel 5

Perilaku Kepala Keluarga mengenai PSN DBD

\begin{tabular}{cccc}
\hline No & Perilaku & $\begin{array}{c}\text { Jumlah } \\
\text { (N) }\end{array}$ & Persentase (\%) \\
\hline 1 & Buruk & 0 & 0 \\
2 & Cukup & 14 & 14,58 \\
3 & Baik & 82 & 85,42 \\
\hline & Total & $\mathbf{9 6}$ & $\mathbf{1 0 0}$
\end{tabular}

Berdasarkan tabel di atas dapat dilihat bahwa dari 96 orang $\mathrm{KK}$ sebanyak 14 orang $(14,58 \%)$ memiliki kategori perilaku cukup, sedangkan sisanya sebanyak 82 orang KK $(85,42 \%)$ memiliki kategori perilaku baik.
Tabel 6

Nilai Item Kuesioner Perilaku

\begin{tabular}{ccccc}
\hline No & Pertanyaan & Ya & Tidak & $\begin{array}{c}\text { Jumlah } \\
\text { Nilai }\end{array}$ \\
\hline 1 & P1 & 96 & 0 & 96 \\
2 & P2 & 96 & 0 & 96 \\
3 & P3 & 83 & 13 & 83 \\
4 & P4 & 30 & 66 & 30 \\
5 & P5 & 88 & 8 & 88 \\
6 & P6 & 96 & 0 & 96 \\
7 & P7 & 83 & 13 & 83 \\
8 & P8 & 64 & 32 & 64 \\
9 & P9 & 96 & 0 & 96 \\
10 & P10 & 18 & 78 & 18 \\
11 & P11 & 71 & 25 & 71 \\
12 & P12 & 83 & 13 & 83 \\
13 & P13 & 95 & 1 & 95 \\
14 & P14 & 77 & 19 & 77 \\
15 & P15 & 54 & 42 & 54 \\
\hline & RATA-RATA & & 75,33 \\
\hline
\end{tabular}

Berdasarkan tabel 7 di atas dapat dilihat bahwa dari 15 pertanyaan rata-rata nilai tiap pertanyaan yang di jawab oleh 96 KK adalah 75,33. Dari 15 pertanyaan, nilai pertanyaan yang masih di bawah rata-rata antara lain pertanyaan nomor 4 (Apakah Anda mengubur barang bekas yang dapat menampung air hujan?), 8 (Apakah Anda menaburkan abate sesuai dengan aturan pakai?), 10 (Apakah Anda menanam tanaman pengusir nyamuk?), 11 (Apakah Anda mengatur cahaya dan ventilasi di dalam rumah?), dan 15 (Apakah 
semua anggota keluarga Anda tidak menggantungkan baju di rumah?).

\section{PEMBAHASAN}

Berdasarkan hasil wawancara diperoleh seluruh KK memiliki kategori tingkat pengetahuan baik mengenai PSN DBD. Namun, nilai pertanyaan yang masih di bawah rata-rata antara lain pertanyaan nomor 4 (Nyamuk penular penyakit DBD berkembangbiak di air kotor), 7 (Fogging atau diasapi lebih efektif menanggulangi penyakit DBD dibandingkan dengan cara PSN), 8 (Aturan waktu minimal dalam pemantauan jentik nyamuk dan PSN 3M plus adalah satu bulan sekali), 11 (Menaburkan bubuk abate di tempat penampungan air boleh sekiranya tanpa aturan), 14 (Menutup lubang pohon termasuk kegiatan PSN), 19 (Kegiatan $3 \mathrm{M}$ plus dirumah hanya boleh dilakukan orang tertentu saja.), dan 20 (Memelihara ikan di bak mandi termasuk kegiatan PSN).

Nyamuk Aedes aegypti berkembangbiak di tempat-tempat penampungan air yang mengandung air jernih atau air yang sedikit terkontaminasi seperti bak mandi, tangki penampungan air, ember, vas bunga, kaleng bekas, kantong plastik bekas, ban bekas, tempurung kelapa, dan pelepah tanaman ${ }^{6}$.

Salah satu cara untuk memberantas nyamuk Aedes aegypti adalah dengan melakukan Fogging. Sebenarnya fogging kurang tepat, karena cara ini sesungguhnya hanya bertujuan untuk memberantas nyamuk Aedes aegypti dewasa, sehingga jika di beberapa rumah penduduk masih ditemukan jentik nyamuk, maka dimungkinkan penularan demam berdarah masih berlanjut dengan dewasanya jentik yang menjadi nyamuk ${ }^{7}$.

Menurut Surat Edaran Nomor PM.01.11/Menkes/591/2016 Tentang Pelaksanaan PSN 3M Plus dengan Gerakan Satu Rumah Satu Jumantik, kegiatan pemantauan jentik nyamuk dan PSN 3M Plus harus dilakukan di rumah masing-masing secara rutin seminggu sekali melakukan.

Saat hujan turun dan air tergenang pada lubang pohon, maka nyamuk Aedes aegypti bisa saja bertelur di tempat tersebut tanpa diketahui pemilik rumah. Partisipasi seluruh anggota keluarga dalam PSN DBD sangat penting. Dengan adanya partisipasi seluruh anggota keluarga sangat membantu untuk mencegah 
terjadinya DBD karena yang berperan penting dalam menjaga kebersihan dan kesehatan rumah adalah keluarga sendiri ${ }^{8}$. PSN 3M dapat diiringi dengan kegiatan plus lain, salah satunya pengendalian biologis dengan memelihara ikan pemakan jentik. Contoh ikan pemakan jentik antara lain ikan cupang/ Betta spp, ikan mas/ Cyprinus carpio dan ikan nila/ Oreochormis niloticus.

Berdasarkan hasil wawancara diperoleh sebanyak 14 orang $(14,58 \%)$ memiliki kategori perilaku cukup, sedangkan sisanya sebanyak 82 orang $\mathrm{KK}(85,42 \%)$ memiliki kategori perilaku baik. Dari 15 pertanyaan pada lembar kuesioner, nilai pertanyaan yang masih di bawah rata-rata antara lain pertanyaan nomor 4 (Apakah Anda mengubur barang bekas yang dapat menampung air hujan?), 8 (Apakah Anda menaburkan abate sesuai dengan aturan pakai?), 10 (Apakah Anda menanam tanaman pengusir nyamuk?), 11 (Apakah Anda mengatur cahaya dan ventilasi di dalam rumah?), dan 15 (Apakah semua anggota keluarga Anda tidak menggantungkan baju di rumah?).
Mengubur barang-barang bekas (kaleng, ban, dan lain-lain) yang dapat menampung air hujan merupakan salah satu upaya pemberantasan jentik secara fisik. Hal ini di dukung dengan penelitian yang dilakukan oleh Anggara (2005) di wilayah kerja Puskesmas Dahlia Kota Makassar yang menunjukkan bahwa ada hubungan antara mengubur barang-barang bekas dengan keberadaan larva Aedes Aegypti ${ }^{9}$ Namun, karena keterbatasan lahan kepala keluarga lebih banyak memilih untuk membuang barang-barang bekas yang dapat menampung air hujan di tempat sampah.

Pemberian larvasida berupa butiran pasir temephos $1 \%$ merupakan cara yang hingga saat ini masih ampuh untuk memberantas larva nyamuk Aedes sp selama 8-12 minggu. Butiran pasir temephos $1 \%$ yang selama ini dikenal masyarakt luas dengan nama abate. Penggunaan abate dalam penanganan kejadian demam berdarah di Indonesia sudah sejak tahun 1976 atau sudah digunakan lebih dari 30 tahun, sehingga penggunaan insektisida yang berulang dapat menambah 
resiko kontaminasi residu pestisida dalam air, terutama air minum ${ }^{10}$.

Keterbatasan lahan menjadi alasan sebagian besar KK tidak tertarik menanam tanaman pengusir nyamuk. Padahal itu merupakan salah satu alternatif lain sebagai insektisida nabati/bioinsektisida yang efektif dalam menekan dan mengendalikan populasi nyamuk vektor. Contohnya kayu putih, cengkeh, geranium, jeruk bali, jeruk manis, jeruk nipis, kecombrang, kemangi dan masih banyak lagi ${ }^{11}$.

Intensitas cahaya merupakan faktor terbesar yang mempengaruhi aktifitas terbang nyamuk dan cahaya yang rendah merupakan kondisi yang baik bagi nyamuk. Kurangnya sinar matahari yang masuk ke dalam rumah menyebabkan kelembaban tinggi dan potensial menjadi tempat perkembangbiakan jentik nyamuk Aedes aegypti ${ }^{12}$. Selain itu, Kemenkes RI mengemukakan bahwa pakaian yang digantung merupakan salah satu tempat peristirahatan nyamuk

\section{SIMPULAN DAN SARAN}

Berdasarkan hasil penelitian dapat ditarik kesimpulan sebagai berikut :
1) Tingkat pengetahuan dari 96 orang kepala keluarga mengenai PSN DBD di wilayah kerja UPT Puskesmas Kuta Selatan diperoleh seluruh KK memiliki kategori tingkat pengetahuan baik mengenai PSN DBD; 2) Perilaku mengenai PSN DBD dari 96 orang kepala keluarga di wilayah kerja UPT Puskesmas Kuta Selatan diperoleh sebanyak 14 orang $(14,58 \%)$ memiliki kategori perilaku cukup, sedangkan sisanya sebanyak 82 orang KK $(85,42 \%)$ memiliki kategori perilaku baik. Saran yang dapat disampaikan yaitu 1) Sebaiknya masyarakat mempertahankan pengetahuan yang baik dan meningkatkan perilaku mengenai PSN DBD dengan mengubur barang bekas yang dapat menampung air hujan, menaburkan abate sesuai dengan aturan pakai dan menanam tanaman pengusir nyamuk; 2) Untuk Puskesmas sebaiknya lebih meningkatkan dan memperbanyak sosialisasi mengenai PSN DBD kepada masyarakat.

\section{DAFTAR PUSTAKA}

1 A. Candra, Demam Berdarah Dengue: Epidemiologi, Patogenesis, dan Faktor Risiko Penularan, Aspirator Vol. 2 No. 2 Tahun 2010 : 
$110-119,2010$.

2 R. Fakhriadi, F. Yulidasari and R. Setyaningrum, FAKTOR RISIKO PENYAKIT DEMAM BERDARAH DENGUE DI WILAYAH KERJA PUSKESMAS GUNTUNG PAYUNG KOTA BANJARBARU (TINJAUAN TERHADAP FAKTOR MANUSIA, LINGKUNGAN, DAN KEBERADAAN JENTIK), Jurnal Publikasi Kesehatan Masyarakat Indonesia, Vol. 2 No. 1, April 2015, 2015.

3 R. N. Husna, N. E. Wahyuningsih and Dharminto, HUBUNGAN PERILAKU 3M PLUS DENGAN KEJADIAN DEMAM BERDARAH DENGUE (DBD) DI KOTA SEMARANG (STUDI DI KOTA SEMARANG WILAYAH ATAS), Semarang: JURNAL KESEHATAN MASYARAKAT (e-Journal) Volume 4, Nomor 5, Oktober 2016 (ISSN: 2356-3346) , 2016.

4 D. Kriastuti, Pengaruh Pengetahuan dan Sikap Terhadap Perilaku Hygiene Penjamah Makanan di Kantin SMA Muhamaddiyah 2 Surabaya, Surabaya: e-journal Boga Vol 5 No 2, 2016.

5 I. W. Ginandra, HUBUNGAN TINGKAT PENGETAHUAN KEPALA KELUARGA DENGAN PERILAKU PENCEGAHAN DEMAM BERDARAH DENGUE DI DESA SENDANGMULYO KABUPATEN BLORA, Surakarta: Skripsi FAKULTAS KEDOKTERAN UNIVERSITAS MUHAMMADIYAH SURAKARTA, 2015.
6 F. Nadifah, N. F. Muhajir, D. Arisandi and M. D. O. L. obo, IDENTIFIKASI LARVA NYAMUK PADA TEMPAT PENAMPUNGAN AIR DI PADUKUHAN DERO CONDONG CATUR KABUPATEN SLEMAN, Yogyakarta: Jurnal Kesehatan Masyarakat Andalas Vol. 10, No. 2, Hal. 172-178, 2016.

7 Ambarwati, S. Darnoto and D. Astuti, FOGGING SEBAGAI UPAYA UNTUK MEMBERANTAS NYAMUK PENYEBAR DEMAM BERDARAH DI DUKUH TUWAK DESA GONILAN, KARTASURA, SUKOHARJO, Surakarta: Warta Vol .9, No. 2, September 2006: 130 - 138, 2005.

8 S. Ummuhani, Pengaruh Pemberdayaan Jumantik Mandiri Keluarga Terhadap Perilaku Keluarga dalam Pencegahan DBD di Niten Nogotirto Gamping Sleman Yogyakarta, Yogyakarta: Skripsi Program Studi Ilmu Keperawatan Sekolah Tinggi Ilmu Kesehatan Aisyiyah Yogyakarta, 2014.

9 I. A. Putri, Hubungan Tempat Perindukan Nyamuk dan Perilaku Pemberantasan Sarang Nyamuk (PSN) dengan Keberadaan Jentik Aedes Aegypti di Kelurahan Benda Baru Kota Tangerang Selatan Tahun 2015, Tangerang, 2015.

10 S. Basri and H. Erlina, PENGGUNAAN ABATE DAN Bacillus Thuringensis var. Israelensis DI KANTOR KESEHATAN PELABUHAN KELAS II SAMARINDA WILAYAH KERJA SANGGATA TERHADAP KEMATIAN LARVA Aedes sp., Makasar: AL-SIHAH VOLUME IX, NO. 1, JANUARI-JUNI 2017, 2017. 
11 S. Zen and R. Noor,

Higiene Volume E 1, NO. 2, 2015.

INVENTARISASI TANAMAN

YANG BERPOTENSI SEBAGAI

BIOINSEKTISIDA NYAMUK

Aedes Aegypti DI KOTA METRO

PROVINSI LAMPUNG, Lampung:

BIOEDUKASI, VOL. 7. NO 2. NOV

2016, 2016.

12 A. Anwar and A. Rahmat, Hubungan

Kondisi Lingkungan Fisik dan

Tindakan PSN Masyarakat Dengan

Container Index Jentik Ae. aegypti di

Wilayah Buffer Bandara Temindung

Samarinda, Samarinda: Jurnal 